\title{
Avoiding the Alveolar Nerve Via a Real-Time Impedance Analysis: A Novel Method to Improve Implant Surgery Safety
}

\author{
Dissertation \\ zur Erlangung des akademischen Grades \\ Dr. med. dent.
}

an der Medizinischen Fakultät

der Universität Leipzig

eingereicht von:

Georg Schiffers

Geburtsdatum / Geburtsort:

12.07.1981 / Geilenkirchen

angefertigt an der:

Universität Leipzig, Klinik und Poliklinik für Mund-, Kiefer- und Plastische Gesichtschirurgie

Betreuer:

Univ.-Prof. Dr. med. Dr. med. dent. Bernd Lethaus, MHBA

Beschluss über die Verleihung des Doktorgrades vom: 19.10.2021 


\section{Inhaltsverzeichnis}

1. Einführung

2. Publikationsmanuskript

3. Zusammenfassung

4. Literaturverzeichnis

5. Darstellung des eigenen Beitrags

6. Selbstständigkeitserklärung

7. Lebenslauf

8. Danksagung
$3-11$

$12-19$

$20-22$

$23-25$

26

27

$28-29$

30 


\section{Einführung}

Das Verfahren, welches im Rahmen der vorgelegten Studie in der Juni Ausgabe 2020 des Journal of medical Devices der American Association of Mechanical Engineers erstmalig veröffentlicht wurde, stellt eine neuartige Methode zur intraoperativen Bestimmung der Distanz zwischen einem Bohrer oder Implantates zum N. alveolaris inferior in Echtzeit dar.

Es entstand in Zusammenarbeit zwischen dem Institut für Vernetzte Systeme iNets der RWTH Aachen unter Prof. Petri Mähönen, Prof. Dr. Bernd Lethaus, erst ebenfalls an der RWTH Aachen, im Folgenden an der Klinik und Poliklinik für Mund-, Kiefer- und Plastische Gesichtschirurgie des Universitätsklinikums Leipzig und dem Autor.

Die Einleitung gliedert sich dabei in eine implantologische, zahnmedizinische Betrachtung mit einer Rationalen für die Studie, einen Teil zur Darlegung der technischen Grundlagen sowie einer Herleitung und Darstellung des neu entwickelten Verfahrens mit Ergebnissen und Diskussion.

\section{Implantologische Aspekte}

Dentale Implantate haben sich im Laufe der letzten Jahrzehnte als Therapieoption fest in der Zahnheilkunde etabliert. Weltweit werden jährlich Millionen Implantate inseriert, in Deutschland allein ca. 1,3 Millionen.

In allen Bereichen der Implantologie, in der Indikationsstellung, der Diagnostik mit Bildgebung, dem Implantatdesign, dem Knochenmanagement, den operativen Verfahren, sowie der Nachsorge fanden in diesem Zeitraum deutliche Entwicklungen hin zur Verbesserung der Ergebnisse und Prozessqualität statt.

Dem operativen Procedere kommt dabei sowohl für den langfristigen Erfolg als auch für die Vermeidung von iatrogenen Schädigungen eine besondere Rolle zu. Neben allgemeinen 
Risiken wie Nachblutungen, manuellen oder systembedingten (bei navigierten Implantationen) Fehlern bei der Positionierung, kommt hierbei der Schädigung des $\mathrm{N}$. alveolaris inferior eine bedeutsame Rolle zu, die daher auch zu den unbedingt aufklärungspflichtigen Risiken mit starker forensischer Wichtigkeit gezählt wird, insbesondere da 25\% der Patienten mit iatrogener Schädigung eine permanente Nervenschädigung behalten.

Dabei ist eine Verletzung dieses Nerven nicht der einzig relevante Faktor in der implantologischen Betrachtung. Zwar möchte man den Nerven keinesfalls touchieren und benachbarte anatomische Strukturen maximal schonen, andererseits aber auch den vorhandenen Knochen möglichst optimal und meist zur Gänze als Implantatlager ausnutzen.

Um diesen Vorgaben zu entsprechen haben sich standardisierte Vorgehensweisen entwickelt. Dazu zählen 2D Aufnahmen mit Referenzobjekten sowie die 3D Bildgebung mit den entsprechenden Messmöglichkeiten sowie der Einsatz von Navigationsschablonen. Auch die operative Ausbildung aber auch tagesaktuelle Konstitution des jeweiligen Operateurs spielen hier eine Rolle.

Diese Verfahren sind prä- oder postoperative Vorsichtsmaßnahmen, haben wiederum eigene Fehlerquoten und bieten keine absolute Sicherheit. Zusätzlich ist eine intraoperative Verifizierung im täglichen Einsatz kaum möglich oder praktikabel.

Hier Abhilfe zu leisten ist Ziel des im anschließenden Artikel vorgestellten Verfahrens und stellt die Rationale für diese Studie dar.

\section{Rationale}

Die klinische Relevanz und damit die Rationale für die vorgelegte Studie ergeben sich primär aus den im folgenden aufgeführten Punkten:

1. Steigerung der operativen Sicherheit bei Implantationen im Bereich des N. alveolaris inferior durch Vermeidung einer operationsbedingten Verletzung bei 
2. gleichzeitiger Möglichkeit das vorhandene Knochenlager größtmöglich für eine Implantation zu erschließen.

3. Anwendung eines solchen Detektionsverfahrens in anderen Bereichen der zahnärztlichen und allgemeinmedizinischen Chirurgie, um auch hier Risiken zu minimieren und Gewebevolumen nutzbar zu machen.

\section{Impedanz in der Elektrik}

Impedanz, vom lateinischen „impedire“, zu Deutsch hemmen oder hindern, bezeichnet im elektrischen Zusammenhang einen Wechselstromwiderstand, also das Verhältnis der beiden Eigenschaften der elektrischen Spannung und der Stromstärke, wenn zwischen den beiden Werten eine Phasenverschiebung besteht.

Die Impedanz ist die komplexwertige Funktion der Frequenz und stellt die Zusammenfassung von den zwei Grundwerten:

1. dem Verhältnis der Amplituden von sinusförmiger Wechselspannung zu sinusförmigem Wechselstrom und

2. der Verschiebung der Phasenwinkel zwischen diesen beiden Größen

dar. Beide Eigenschaften werden durch Darstellung der Impedanz als komplexe Größe mathematisch zusammengefasst. Das Einheitenzeichen der Impedanz ist Z. Sie wird in Ohm angegeben.

Die Impedanzwerte von biologischen Geweben unterscheiden sich mitunter erheblich und können, wie beispielsweise in der Endodontie seit langem, zur Abgrenzung unterschiedlicher Gewebe genutzt werden. 


\section{Impedanz in der Zahnheilkunde}

Eine genauere Betrachtung der Entwicklung von Impedanzmessverfahren in der Zahnheilkunde lohnt, da diese als erste Inspiration für die im Artikel vorgestellte neue Herangehensweise diente und sich Grundlagen daran verdeutlichen lassen.

Erste Ansätze zu elektrischen Widerstandsmessverfahren in der Zahnheilkunde wurden bereits 1916 beschrieben. Das Desmodont hat, ungeachtet der Zahngröße, des umgebenden Gewebes oder des Zahnzustandes einen konstanten Gewebewiderstand von 6 kOhm. Wird mit einer Gleichstromquelle dieser Widerstand zwischen einem im Wurzelkanal befindlichen Instrument und einer Schleimhautelektrode erreicht, konnte daraus auf die Wurzelkanallänge geschlossen werden. Allerdings war das Verfahren wegen Polarisationsprozessen an Kathode und Anode Fehleranfällig und wurde durch weitere Entwicklungsschritte verbessert.

Mit einer Wechselstromquelle verhinderte man, gerade bei höheren Frequenzen, Polarisationsprozesse an der Elektrodenspitze. Die damit jetzt messbare Impedanz setzt sich aus dem ohmschen Gewebewiderstand und der kapazitiven Komponente zusammen. Wenn jetzt ein Instrument das Desmodont erreicht, kann die Gewebeimpedanz gemessen werden, die mit einem vorprogrammierten Mittelwert verglichen wird, und das Erreichen des Foramen physiologicum kann signalisiert werden. In einem trockenen Wurzelkanal funktioniert dieses Verfahren zuverlässig. In einem, durch Blut oder Spülflüssigkeit, feuchten Wurzelkanal hingegen versagt dieser Ansatz wegen der sich aufbauenden Elektrodenimpedanzen (zwischen Instrument=Elektrode und der ionischen Flüssigkeit um sie herum). Diese Elektrodenimpedanz addiert sich zum Gewebewiderstand zwischen Mundschleimhaut und Desmodont, der ja den an sich relevanten Messwert darstellt. Deshalb wurde auch dieser Ansatz wieder verlassen.

Der nächste Schritt für die 3. Generation dieser Messgeräte war die Abkehr von der Messung absoluter Werte der Impedanz als Referenzwert für die Erreichung des Apex hin zur rechnerischen Bestimmung eines Quotienten aus zwei Impedanzwerten bei verschiedenen Frequenzen. Die gerade beschriebene Elektrodenimpedanz wird nun als eigener Messwert 
erhoben. Da diese stärker von der Wechselstromfrequenz abhängt als die Gewebeimpedanz, kann die Elektrodenimpedanz über die Ermittlung eines Wertes aus zwei, bei unterschiedlichen Frequenzen gemessenen, Gesamtimpedanzen berechnet werden. Als Graph dargestellt könnte man sich dies als zwei erst eher parallel laufende Linien vorstellen (X-Achse stellt die Frequenz, Y-Achse die Distanz zum Wurzelkanalausgang dar), die ab einem bestimmten Punkt (dem apikalen Foramen) verschieden stark ansteigen.

\section{Anwendung in dieser Studie}

Mittels eines Impedanzmessverfahrens zeigen wir am Tiermodell eine Möglichkeit, den intraossären Abstand eines Bohrers / Implantats zum N. Alveolaris inf. zu bestimmen. Da der Knochen aber keinen konstanten Isolator, wie die Dentinwände eines Wurzelkanals, darstellt, versagen hier bisher bekannte Messmethoden und neue Ansätze müssen zum Einsatz kommen.

\section{Vorversuche}

Auch im hier propagierten Messverfahren haben wir im Laufe der Zeit durch stetige Weiterentwicklung sowohl eine Steigerung der Genauigkeit als auch der Aussagekraft durchlaufen.

Erste Versuche am iNets am Tierknochen im Jahr 2010 zeigten, dass das Verfahren Potential zur weiteren Nachverfolgung hat. Versuche im Rahmen eines Humanpräparatekurses an der Klinik für Mund-, Kiefer und Gesichtschirurgie der RWTH Aachen zeigten, dass sich die ersten Ergebnisse auch auf ein Humanpräparat übertragen ließen.

Analog den Entwicklungen in der Endometrie, haben wir im Laufe der Vorversuche weitere mess- und berechenbare Faktoren in die Betrachtung mit einbezogen. Nur so ließen sich die schlussendlich erreichten guten Aussagewerte in der finalen Studie realisieren. 


\section{Propagiertes Messprinzip}

Wir knüpfen generell daran, keine einzelnen, absoluten Impedanzwerte zu erheben, behalten aber das Prinzip von zwei Elektroden bei. Diese sind der elektrisch angeschlossene Bohrer oder das Implantat selbst sowie eine lose Schleimhautelektrode.

Allerdings fügen wir der Messung den Faktor eines Frequenzverlaufes zwischen $100 \mathrm{~Hz}$ bis in den Bereich von bis zu $250 \mathrm{MHz}$ hinzu, der (für diesen Entwicklungsschritt noch) in ca. 9 Sekunden durchfahren wird. Die so erhaltenen Verlaufskurven der Impedanz zeigen einen Verlauf, der sich einem bestimmten Abstand zum N. alveolaris inferior zuordnen lässt. Aus der kurvenanalytischen Auswertung von einzelnen, spezifischen Kurvenarealen bei verschiedenen Frequenzen lassen sich zusätzliche Informationen gewinnen. Dazu zählt beispielsweise ein charakteristischer Kurvenanstieg bei einem Abstand von $2 \mathrm{~mm}$ zum Nerven, den wir als Erreichen der den Nerven umgebenden Compacta einschätzen. Zusätzlich kann sich ein geeigneter Messalgorithmus, aus einem derartigen Kurvenverlauf, selbst stetig re-/ kalibrieren und so zusätzlich Messungenauigkeiten ausschließen. Entsprechende Graphen lassen sich dem Methoden- und Ergebnissteil des Artikels entnehmen.

Diese Messverfahren ließen sich, ähnlich aktuellen Geräten zur endodontischen Aufbereitung, in chirurgischen Motoren und Winkelstücken einbauen. Damit könnte man sowohl eine akustische oder optische Rückmeldung geben als auch einen direkten Eingriff in die Motorsteuerung (Drehmoment oder in die Umdrehungsgeschwindigkeit beim Vorbohren oder der Implantatinsertion) erlauben.

\section{Finales Studiendesign}

Die Konzeption der Studie zielt darauf ab, einen tierexperimentellen Nachweis der Wirksamkeit der vorgeschlagenen Messmethode zu erbringen.

Als Präparat wurden 5 Unterkiefer von Schafen, die naturgegeben einen günstigen zahnlosen Bereich zwischen Seiten- und Frontzähnen aufweisen, herangezogen. In ebendiesem Bereich wurden insgesamt 40 Bohrstellen ausgesucht. In diesen wurden jeweils 3 Bohrschritte 
durchgeführt. Die einzelnen Bohrungen gingen bis in die oberflächliche Kortikalis, ins Knochenmark und den Bereich des Canalis mandibularis.

Nach jedem Bohrschritt wurde jeweils ein DVT des gesamten Kiefers angefertigt sowie das Messverfahren angewendet.

Zur Messung der Impedanzwerte wurde eine entspreche Meßsonde an den zuvor genutzten Bohrer angeschlossen. Die Bohrer verblieben für das anschließende DVT im Kiefer.

Die Distanzen zwischen den Bohrern und des C. mandibularis wurden anschließend in einer entsprechenden 3D Software ausgemessen.

Die gemessenen Werte aus dem Messverfahren konnten so in Relation zu den tatsächlichen Distanzen zwischen Bohrer und Nervkanal gesetzt werden.

Die Nullhypothese, dass kein Zusammenhang zwischen den gemessenen Impedanzwerten und der Eindringtiefe eines Bohrers besteht, konnte so widerlegt werden.

Die verwendeten Kiefer stammten von Tieren aus der Nahrungsmittelgewinnung.

\section{Ergebnisse}

Aus mehreren Vorversuchsabordnungen war zu erwarten, dass sich bei niedrigeren Frequenzen von $100 \mathrm{~Hz}$ bis ca. $10 \mathrm{KHz}$ einem generellen Impedanzlevel ein gewisser Abstand zum Nerven zuordnen lässt. Dazu musste jede Messtelle allerdings für sich kalibriert werden, da sich das Impedanzlevel zwar immer mit der Annäherung an den Canalis mandibularis absenkt, die absoluten Werte allerdings von Bohrstelle zu Bohrstelle voneinander abweichen. Diese Beobachtung wurde auch in dieser Studie bestätigt.

Neu hingegen in der finalen Studie sind Beobachtungen aus der Auswertung des weiteren Kurvenverlaufs zwischen 100 und $200 \mathrm{MHz}$. Hier lassen sich mehrere weitere Parameter der Verlaufskurven als auch anderer elektrischer Eigenschaften, zum Beispiel der Phasenverschiebung, spezifischen Abständen zum Nervkanal eindeutig und reproduzierbar zuordnen. Diese Werte erfordern im Gegensatz zum Verfahren aus den Vorversuchen entweder keine örtliche Kalibrierung oder eine Kalibrierung lässt sich in den Messalgorithmus so integrieren, dass während der eigentlichen Messung erhobene Werte in 
die Berechnung der Distanz einbezogen werden können, so das keine Zeitverzögerung entsteht.

Durch die Auswertung mehrerer der vorgenannten Werte zum gleichen Zeitpunkt lässt sich die Zuverlässigkeit der Abstanderfassung im Gegensatz zur isolierten Betrachtung einzelner Impedanzeigenschaften deutlich verbessern.

\section{Diskussion}

Unsere Ergebnisse zeigen das Impedanzmessverfahren ein hohes Potential haben, klinisch nutzbare, Echtzeitdaten über die Entfernung zum N- alveolaris inferior zu liefern. Als zusätzlicher Befund konnte gezeigt werden, dass durch die Kombination von mehreren gemessenen Impedanzeigenschaften weitere nützliche Informationen erhalten werden können.

Es ist anzumerken, dass sich bei der Übertragung dieser Tierkadaver-basierten Studie in eine in-vivo Situation technische Hindernisse zu überwinden sein könnten. Das Vorhandensein von leitenden Flüssigkeiten (Blut, Speichel) im Operationsfeld oder die elektrische Aktivität den gesamten N. mandibularis könnten die Messergebnisse beeinflussen. Allerdings ergibt sich, wie bereits geschildert, bei der Betrachtung vom Verhältnis einzelner Impedanzwerte zueinander anstatt in Absoluten bereits ein Lösungsansatz.

Auch könnte das Design des verwendeten Bohrers, z.B. durch die Kombination einer leitenden Bohrerspitze und einem isolierenden Schaft, den Erfordernissen angepasst werden.

Das Prinzip dieser Methode lässt sich prinzipiell auf andere chirurgische Verfahren, sowohl im Hart- als auch im Weichgewebe übertragen, und könnte beispielweise in der Orthopädie sinnvoll eingesetzt werden. Auch der Einsatz in Operationsrobotern erscheint sinnvoll, da hier systembedingt jede taktile Rückmeldung fehlt.

Technische, präklinische und klinische Studien wären weiterhin von Nöten, um das Verfahren weiter zu bewerten und gegebenenfalls zu etablieren. 


\section{Publikationsmanuskript}

veröffentlicht im

Journal of Medical Devices

Juni 2020, Vol. 14 / 021003-1

der

American Association of Mechanical Engineers 


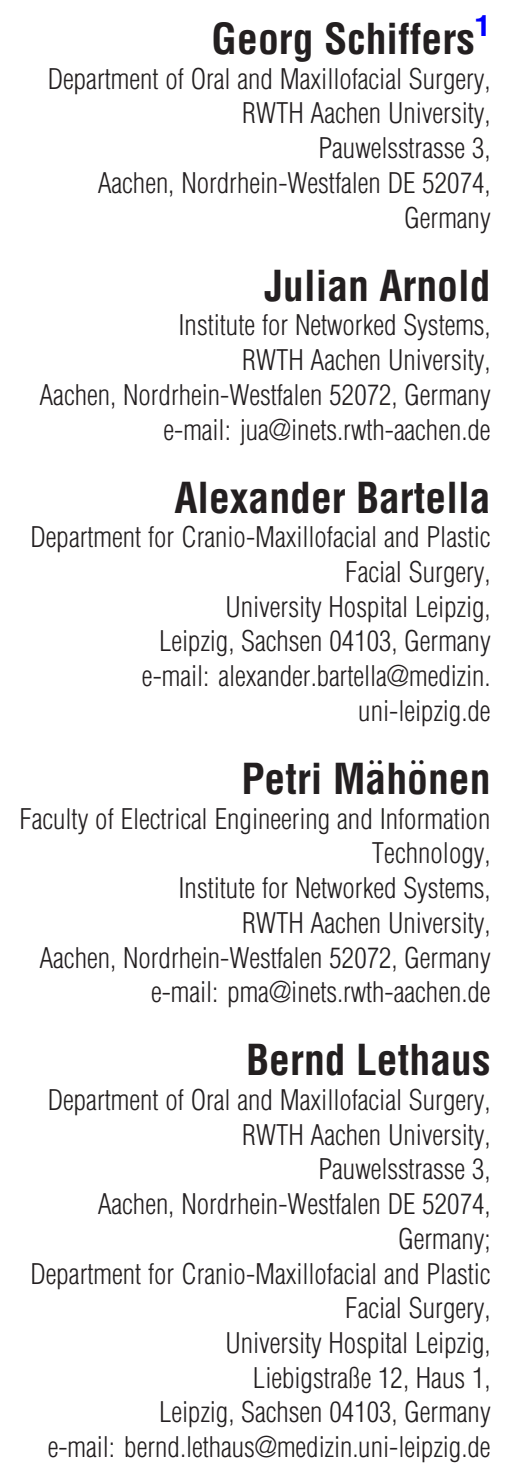

Petri Mähönen

Faculty of Electrical Engineering and Information Technology,

Institute for Networked Systems,

RWTH Aachen University,

Aachen, Nordrhein-Westfalen 52072, Germany e-mail: pma@inets.rwth-aachen.de

Bernd Lethaus

Department of Oral and Maxillofacial Surgery, RWTH Aachen University, Pauwelsstrasse 3 , Aachen, Nordrhein-Westfalen DE 52074, Germany; Department for Cranio-Maxillofacial and Plastic Facial Surgery,

University Hospital Leipzig, Liebigstraße 12, Haus 1 , Leipzig, Sachsen 04103, Germany e-mail: bernd.lethaus@medizin.uni-leipzig.de

\section{Avoiding the Alveolar Nerve Via a Real-Time Impedance Analysis: A Novel Method to Improve Implant Surgery Safety}

Safe lower jaw implantations require precautions to avoid damaging the alveolar nerve. The prevailing methods are preoperative. In this study, we propose a novel approach to measure the distance between a pilot-drill and the alveolar nerve by employing highfrequency impedance measurements. The objective is to provide in vivo real-time information as an early warning of the proximity of the alveolar nerve. The method is examined and tested on animal samples. The impedance measurements were performed using a high-frequency network analyzer. Overall 40 pilot drillings were distributed over five sheep mandibles, with four on each side. Drillings were performed in three steps: inside the cortical layer, inside the spongiosa, and well inside the nerve canal. The inductance measurements were performed with a connected pilot drill, followed by an immediate $3 D$ cone-beam computed tomography $(C T)$ to measure the distance between the tip of the drill and the nerve canal. The measurements show that impedance information is a reliable indicator for proximity of the drill to the nerve. We observe a general trend of decreasing inductance as the drill approaches the nerve and find that at very high frequencies one can detect the closeness to the nerve from characteristic ratios of impedance at nearby frequencies. We report also that using phase information increases the reliability of this method. The findings provide a solid proof of concept for the proposed method. While the results are promising at this stage, the applicability for in vivo conditions requires further studies. [DOI: 10.1115/1.4046212]

\section{Introduction}

With a generally low level of complications even in compromised conditions, the insertion of dental implants has become a routine procedure in oral rehabilitation [1]. Nonetheless, a misplaced implant can result in a variety of intra- and postoperational complications. When dislocated too close to the alveolar nerve, it can cause a decline or loss of sensitivity and severe pain syndrome when the nerve is compressed or severed. This will lead to permanent hypo- or anesthesia of the alveolar nerve with great consequences for the patient's quality of life [2]. If the implant placement is too shallow inside the bone or the diameter is too narrow the long-term survival or the prosthetic value might be impaired [3].

Great advances have been made in implant surgery safety with developments like the digital X-ray with advanced software, the cone beam computed tomography (CBCT), guided implantology, backward planning, and vice versa. A promising way to ensure a

\footnotetext{
${ }^{1}$ Corresponding author.

Manuscript received August 26, 2019; final manuscript received January 19, 2020; published online February 18, 2020. Assoc. Editor: Xiaoming He.
}

safe implantation is to combine 3D X-rays, intra-oral scans, and a planning software to manufacture a $3 \mathrm{D}$ drilling guide with depth restriction [4].

However, all these methods are preoperational and do not offer, for most parts, the possibility of intra-operative confirmation. They can also be subject to operational or systematic errors [5]. Furthermore, most dental implants are still inserted without these high standard clinical guides and 3D CBCT. Thus, it can be concluded that there is still the need to improve the safety of the dental implantation process.

This article investigates the potential of a new method to electronically measure the distance between a pilot drill inside the alveolar bone and the nerve canal. The purpose is to establish a clinical procedure to help to prevent the impairment of the alveolar nerve and provide extra guidance during the implantation process. The method is partially inspired by state-of-the-art impedance apex locators used in endodontic operators [6].

Impedance is, generally speaking, the measure of the opposition that a circuit presents to a current when a voltage is applied. The electrical properties of the bone structure are highly different compared to those of soft tissues and nerves [7]. Thus, it follows that the measured impedance changes when the drill is in a 


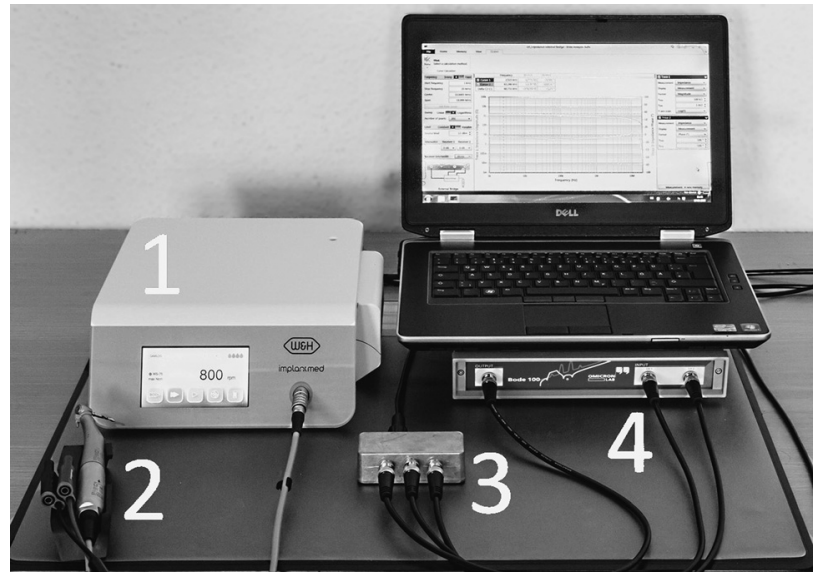

Fig. 1 The measurement setup: (1) surgical handpiece unit (W\&H, Bürmoos, Austria) (4) OmicronLab Bode network analyzer; (3) custom made calibration unit from which the connection to (2) the handpiece and tissue electrodes is done with shielded cabling. The measurement software was run on a laptop that was connected to the network analyzer via a network cable.

different part of biological material. Our hypothesis was also that as the bone structure width changes between the more highly conductive nerve channel and the drill, we would be able to measure the change in the impedance.

The overall aim of our study is to prove the hypothesis that impedance information can be used to probe the closeness of a pilot drill to the N. alveolaris. Furthermore, we want to derive an algorithm to correlate impedance measurements with the actual drilling depth from the CBCTs. We also want to quantitatively confirm the ability of this method to quantify the proximity of the drill and the nerve and the possibility of developing a clinical procedure as shown in the schematic in Fig. 1. Finally, it is also of interest to see to what technical or clinical errors this method might be prone to.
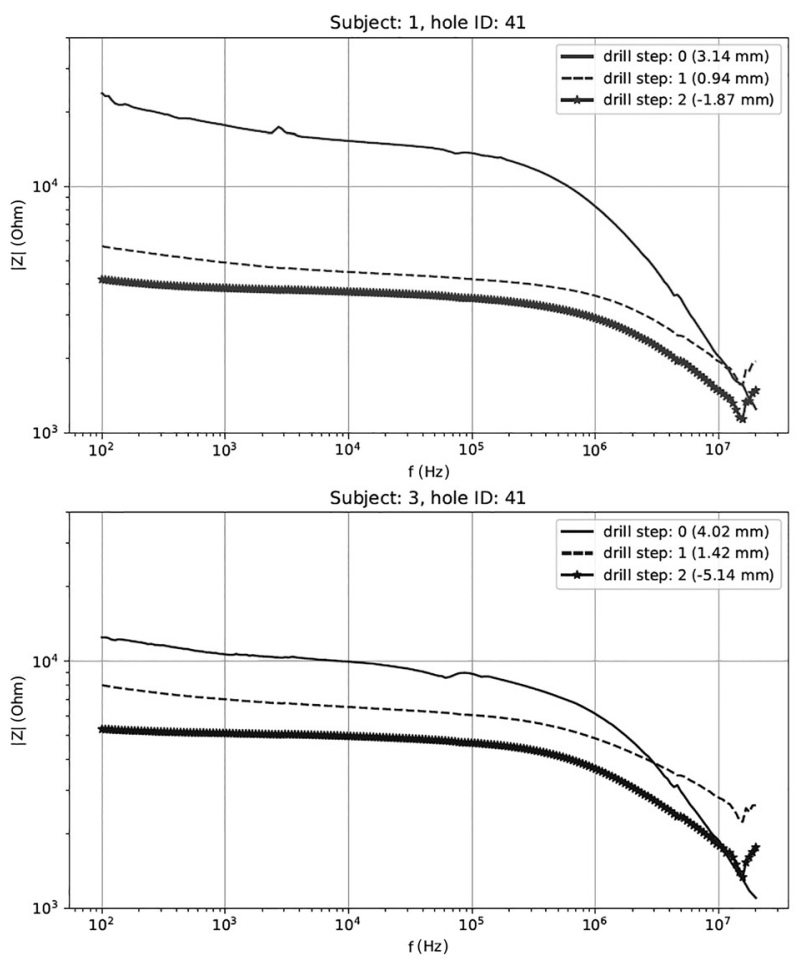

\section{Materials and Methods}

General Experimental Setup. The technical measurement setup is shown in Fig. 1 and consisted of vector network analyzer, surgical handpiece unit, handpiece, tissue electrodes, and computer with the analysis. The used vector network analyzer (VNA) is a Bode 100 from Omicron Lab, Klaus, Austria, with the associated measurement software. The VNA was connected to an external resistive impedance bridge, which we implemented to guarantee impedance matching for high frequencies and accurate measurements. Two biocompatible electronic probes (electrodes) were used for the measurements. One of the probes was connected to the pilot drill and another flat stationary electrode was placed onto the tissue neighboring the lingual foramen of the alveolar nerve of the animal sample.

The impedance measurements are done with the laboratory calibrated network analyzer, which was then impedance matched and connected to the drilling piece. The receiver channel bandwidth was set up to $30 \mathrm{~Hz}$ for all measurements, but we separately tested that now further information could be gained with more narrowband measurements $(10 \mathrm{~Hz})$ and we confirmed that, in fact, also wider bandwidth $(>100 \mathrm{~Hz})$ would be sufficient for our measurements. The detailed testing is left for the future work, where our aim would be to build a dedicated measurement prototype. The overall sweep-time for the measurements was $9.4 \mathrm{~s}$, which is obviously too slow for real-time in vivo measurements. However, the long measurement time is explained by the fact that we covered the large bandwidth with a large number of sampling points. We will comment later in this article the approach to lower the measurement time for practical measurements. Our test measurements did not show any correlation or significant difference in the error bounds when changing the bandwidth or increasing the number of the sampling points from 201 to 1000 .

Five (5) mandibular jaw bones of fresh sheep cadavers were separated from the skull and prepared. The mucosa and the periosteum were removed in the area between the molars and the incisors. Each jawbone was preliminarily marked with one to five round drillings on the vestibular side below the tooth level to be able to distinguish them with certainty in the cone-beam CTs to
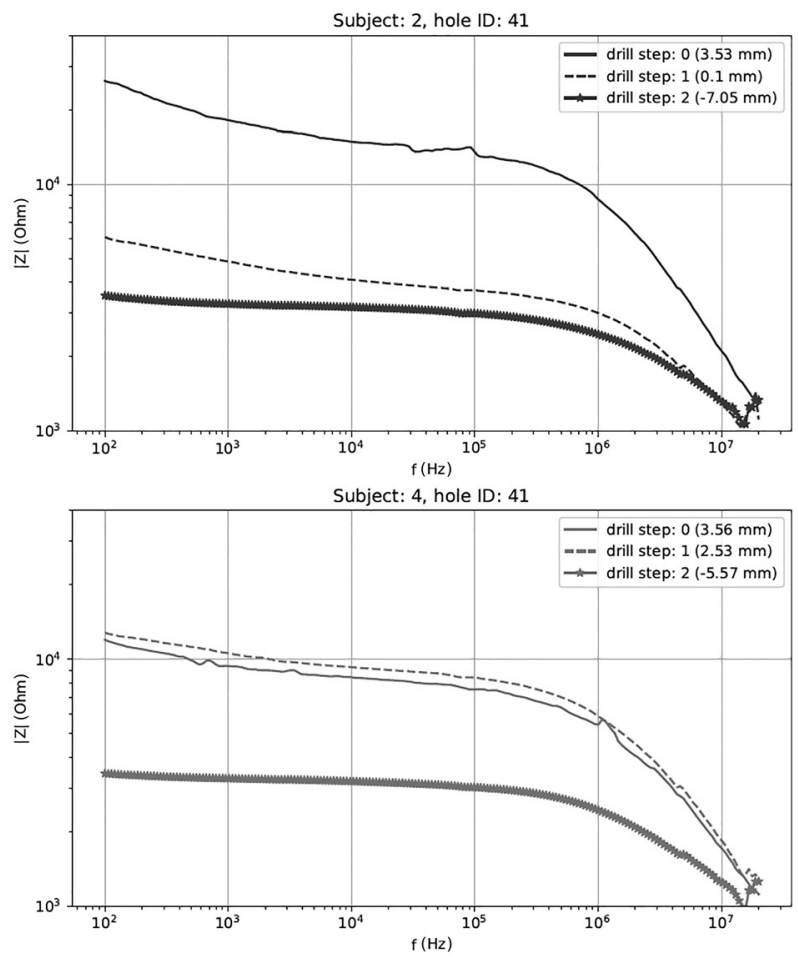

Fig. 2 Typical measurement curves obtained from the described measurement sweeps 
follow. The sheep mandibles were randomly and blindly selected to avoid any selection bias.

For the pilot drillings, single use drills were used with a contraangle surgical handpiece (EP Pilotbohrer, Camlog, Wimsheim, Germany). On each jaw eight points were selected and marked in a toothless area between the molars and the incisors. Then, three consecutive drilling steps were performed on each point. The first round of drillings was made just into the outer corticalis. The second drilling step leads well into the spongiosa of the bone. The third drilling step went into the nerve.

Immediately after each drilling step, the predefined impedance measurement procedure was performed via the connected electrodes as described above. To maximize the collected data, a wideband impedance measurement sweep between $50 \mathrm{~Hz}$ and $40 \mathrm{MHz}$ was conducted. The results were stored on the measurement computer and later transferred into comma-separated values-coded data tables. In Fig. 2, we show the raw measurement information collected from four different drillings in different jaws.

After each of eight drillings at each depth that we performed on a single jaw, a 3D X-ray was done with a Sirona Galileos CBCT (Sirona Dental Systems, Bensheim, Germany). For the second and third steps, the eight drills were left inside the holes to measure distances more accurately in the 3D images; the images were afterward evaluated with the corresponding software (GALILEOS VIEWER, Sirona Dental Systems, Germany). This postoperative analysis allowed us to confirm with certainty in which part of the jawbone the drill was, and we were able to thereby accurately measure the distance between the drill and the nerve. An example of the analysis software and our measurements with 3D X-rays is shown in Figs. 3-5.

In the case of second drilling steps, there were two cases in jaw number 2 where the X-rays showed that we had already hit the nerve. We note that the latter does not affect our analysis since we also obtained distance information from these X-rays. When processing the data, we were also checking if there were any statistical differences across the animals. Apart from the fact that different impedance amplitude levels were detected, due to different bone structure and drilling depths, no statistically significant differences were observed across the studied animals.

The statistical consistency and reliability of the data were considered in the postprocessing. As several measurements were done for each hole and depth level, the VNA is actually reporting the averaged values. We did statistical sampling to check raw data of all measurements from some of the frequencies to see how much there is variation around the average. The reported impedance values are within a few percentage points around from the average, and most importantly, we do not notice any statistical bias, that is, the errors were normally distributed around the average. However, we point that this is an issue for the future studies to check again as the in vivo environment with more challenging conditions may change the situation.

In the further analysis of this article, we are interested in what accuracy we can detect the distance of the drill tip to the nerve. We have measured for each drilling impedance ratios (ZR), slope of impedance over a range (SZ), and monitored the gradient (of phase of the impedance) of very high-frequency components (ZG). The ZR, SZ, and ZG statistics are calculated directly from impendence measurement data that were provided by VNA. The $\mathrm{ZR}$ is simply the ratio between two different impedance values measured in different frequencies, while SZ is calculating linear line slope between impedance values. In the case of the gradient, we calculate the gradient of the phase at very high frequencies $(>10 \mathrm{MHz})$. All of these values were calculated, tabled, and then statistically analyzed. The aim was to find possible threshold values for each parameter that would predict the position of the drill with respect to the nerve.

\section{Results}

The impedance measurements were analyzed in the frequency span of $50 \mathrm{~Hz}$ to $40 \mathrm{MHz}$, and our measurement device had a $30 \mathrm{~Hz}$ channel bandwidth. The measurements validate our hypothesis that the impedance data are highly dependent on the biophysical environment where the drill tip is located [8]. In Fig. 6, we

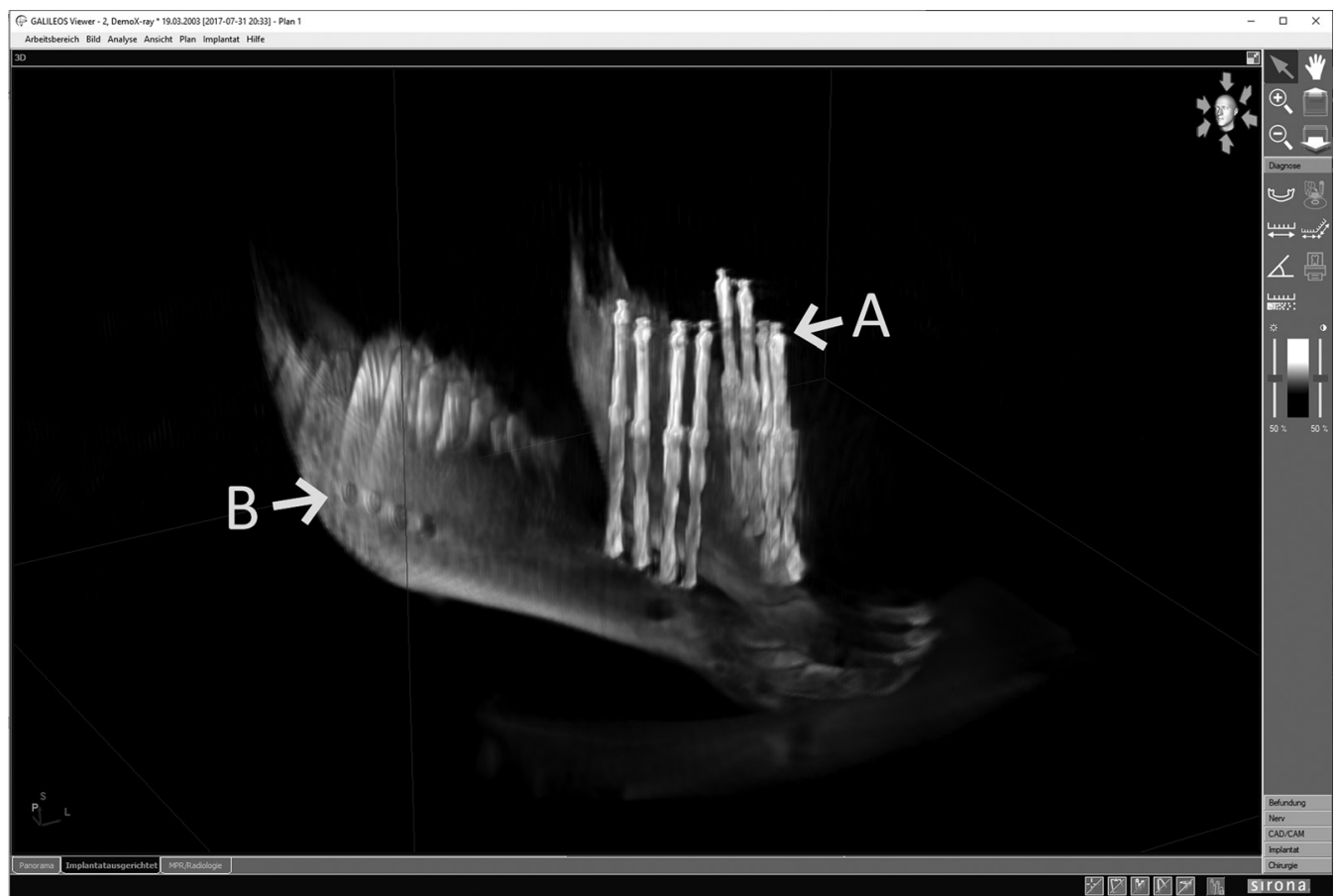

Fig. 3 This picture from the Galileos Software shows the CBCTs capture of the sheep jaws with eight pilot drills (a) positioned into the excavated canals. The individual jaws were assigned numbers from 1 to 5 and marked accordingly with one to five holes on the outward side of the retromolar bone areas (b). 
show the full impedance spectrum from two representative measurements (two different subjects labeled in the figure ID-1 and ID-2)

As the impedance itself is a complex number, we show in the figure the modulus of the impedance, which is a real number indicating its magnitude. One can see from these typical graphs that the measurements provide rich and highly detailed information. The measurements show that, just like in the case of other applications, for example, apex location [9], the absolute magnitude value of the impedance is not alone a reliable indicator, since it changes from subject to subject and is dependent on the physiology of the site where the measurement is done. Nevertheless, the general trend of decreasing impedance with the increasing proximity to the nerve is confirmed.

We fully expected that noncalibrated pure impedance measurement is unlikely to provide clinically usable results. As mentioned, we will calculate the impedance ratios between different frequencies and track that value; this in effect normalizes the changes as long as the distance between different frequencies is large enough. In this work, we also propose the novelty of tracking the slope (smoothness) of the impedance curve over the range of the frequency (an order of magnitude or more) and looking at very high-frequency components over $10 \mathrm{MHz}$ and particularly their phase value. One of the most interesting novel findings in our analysis is that at very high frequencies (above $3 \mathrm{MHz}$ ) the impedance data provide characteristically strong information on the closeness of the nerve.

There are characteristic frequency bands, where the impedance (phase) reacts strongly to the changing resistance changes as a function of the distance from the nerve channel. The observed basic characteristics were similar among all animals and drilling holes. The only observed difference was the absolute (non-normalized) impedance value, but this was to be expected and has no consequence as we are using relative values for the distance estimation.

Although the observed statistical characteristics of impedance spectra were similar among subjects, for the sake of clarity we refer to Fig. 6, when explaining the main findings and what features one can use in the proximity warning (the reader can also consult Fig. 2 for seeing that while amplitude values can be different, the later explained calculated characteristics persist over all subjects). First, the expansion panel in Fig. 6 shows the high end of the measured frequencies. There are two characteristic frequencies there, one is close to $17 \mathrm{MHz}$, where one notices that as long as the drill is far away from the nerve it has a constant downward gradient, but this changes once we are getting closer to nerve the gradient switches to be upward after this point. Second, one observes between 4 and $5 \mathrm{MHz}$ a small 'knee like' feature, where the pure monotonically decreasing impedance trends are broken. There is similar, but opposite and less pronounced, behavior around $10 \mathrm{MHz}$. These 4 and $10 \mathrm{MHz}$ feature disappears as we get closer to the nerve and is totally absent once the nerve is pierced. There are other similar points that one can observe when doing a full frequency domain analysis and using also phase information. Some of them could be also observed in frequencies that are below $3 \mathrm{MHz}$, but there are less unpronounced and at least with our initial analysis do not provide as reliable indications. In our data of five sheep jaws, we thus observed that the best approach is to calculate impendence ratios, slope of the impedance, and gradient change for high-frequency components (beyond 10 and $17 \mathrm{MHz}$ ), and use them as the indicators for the nerve proximity. As seen in the table for being very close to the nerve, it would be enough just to calculate the ratio of impedance for selected highfrequency components. Another strong statistical feature that can be seen is how rapidly the impedance amplitude changes between 1 and $10 \mathrm{MHz}$ As can be seen in Fig. 6, the impedance decreases

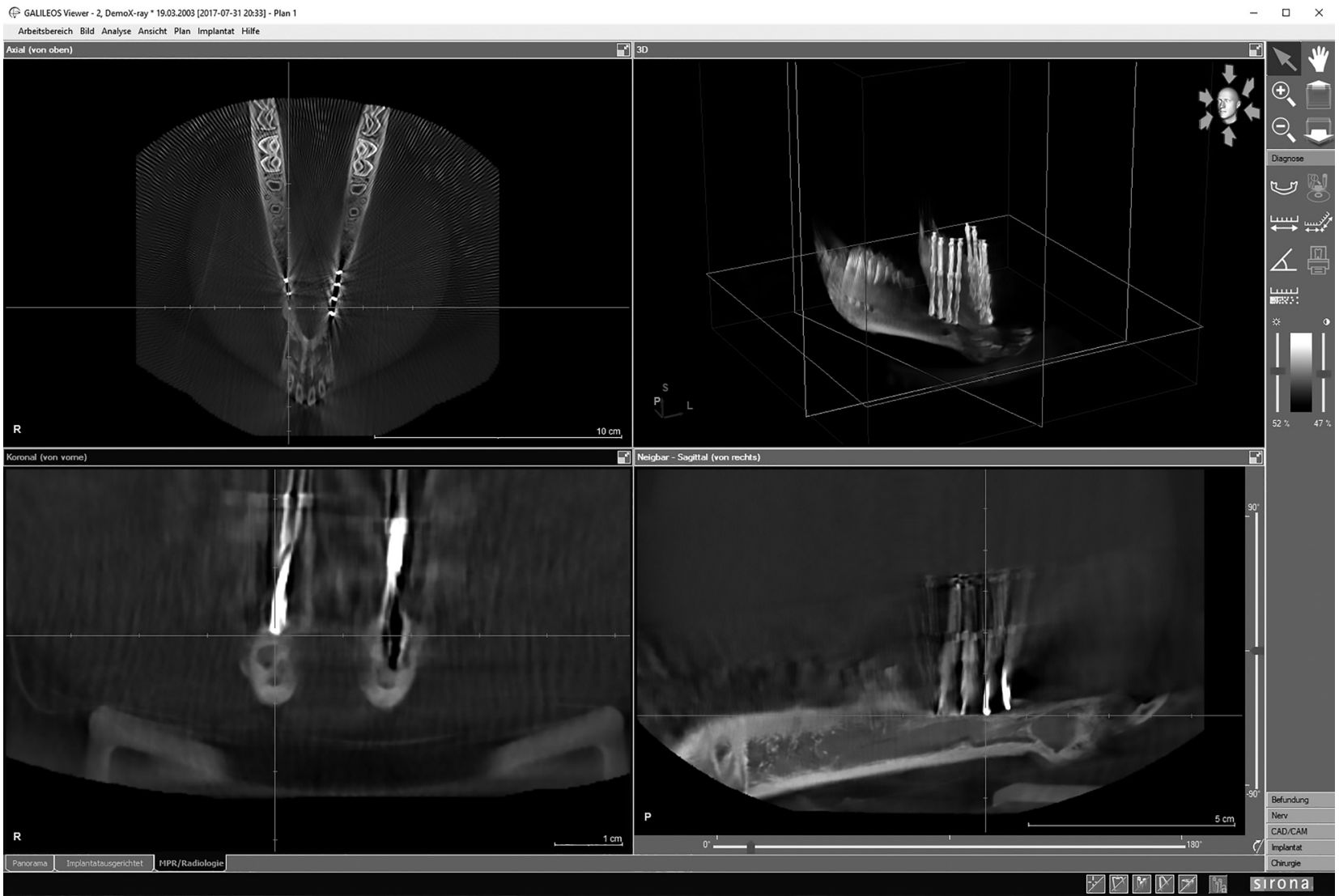

Fig. 4 Each drill tip was located within the 3D software (see the crosshair in the sectional slices on the left on bottom) to be able to measure the exact distance to the nerve canal (see the enlarged Fig. 5) 


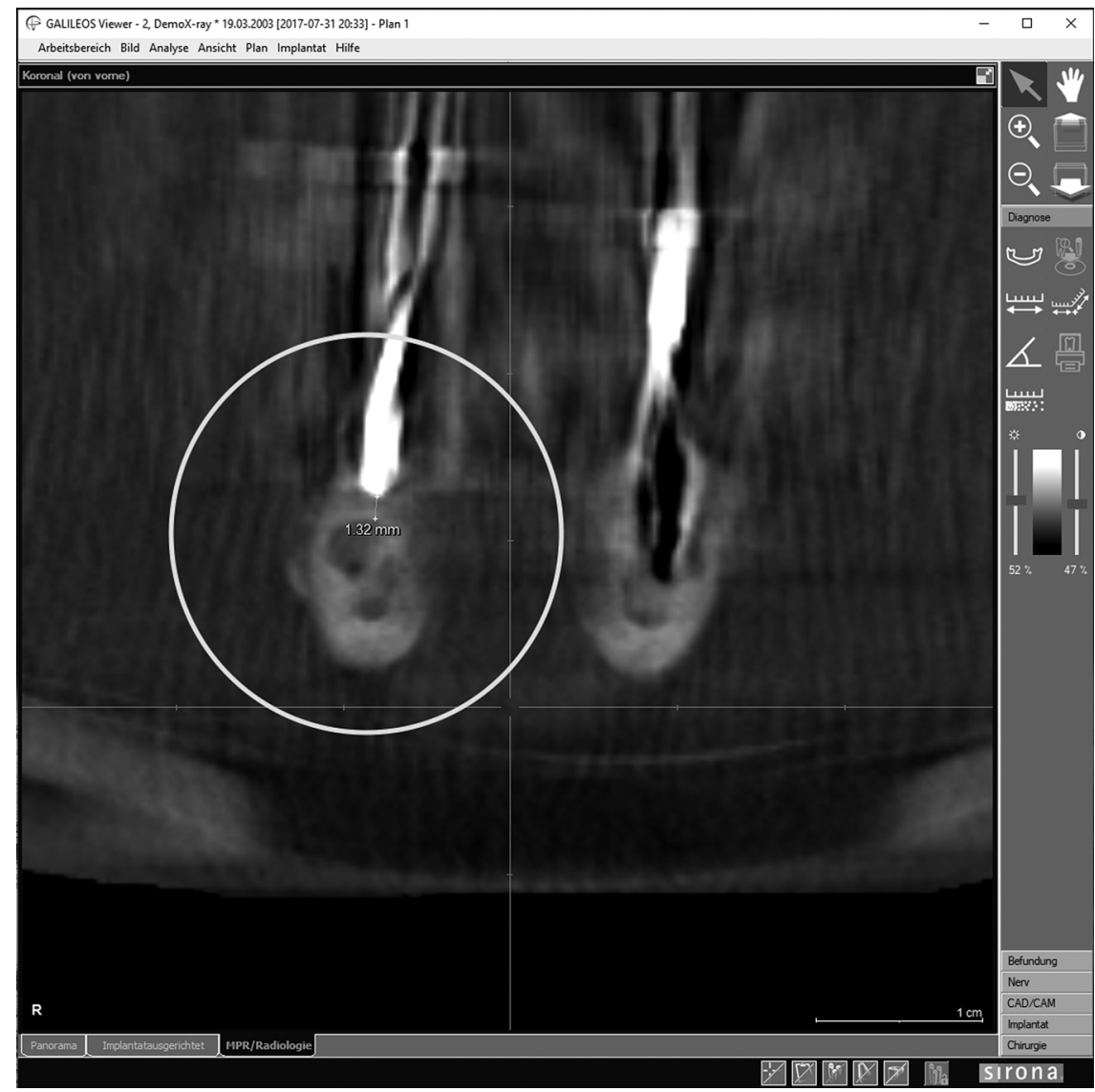

Fig. 5 The software allows for measurements in $1 / 100 \mathrm{~mm}$ steps in the selected cross section (see the encircled area)

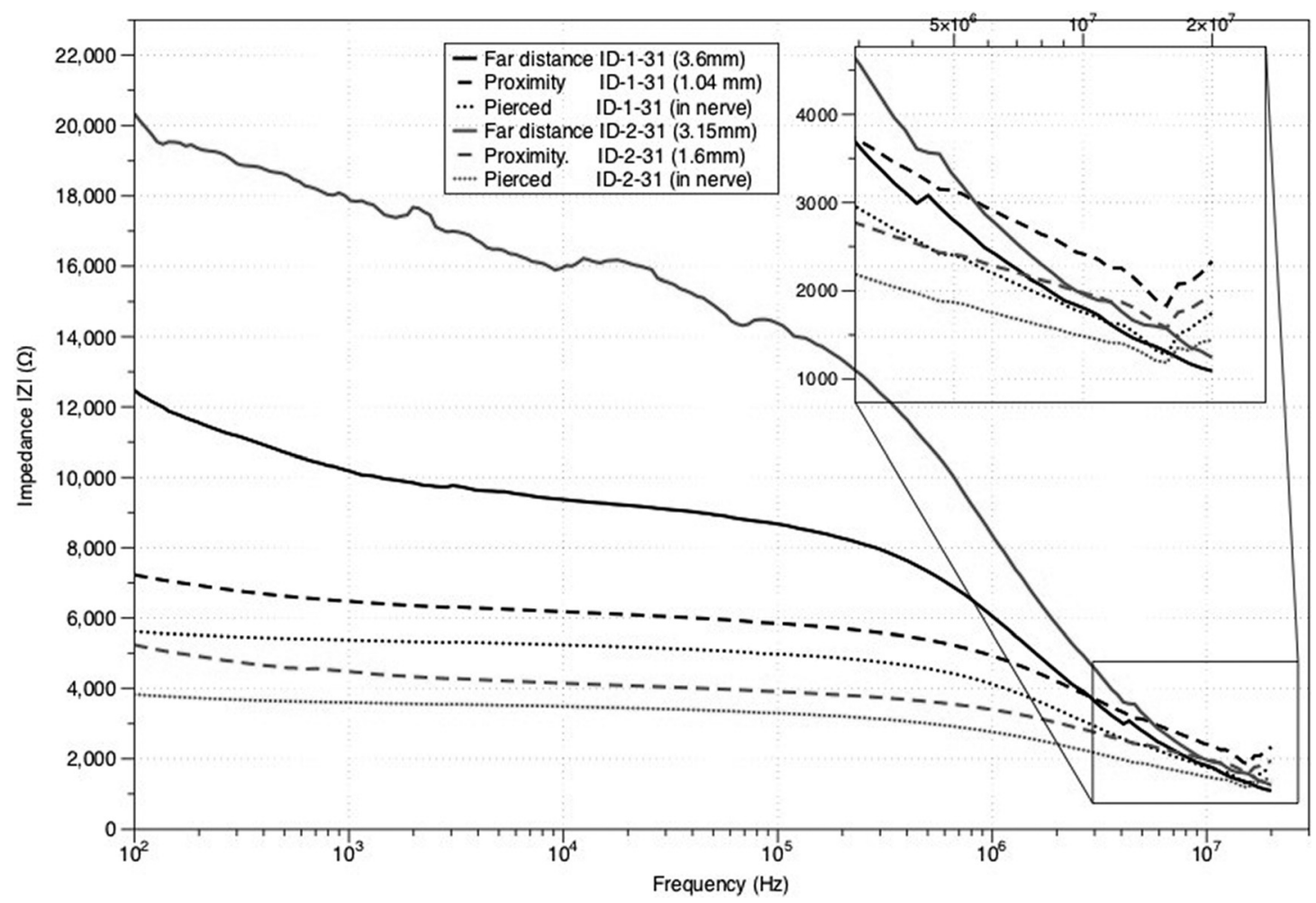

Fig. 6 The results from impedance measurements done for two different tooth positions (ID-1 with black lines and ID-2 with red lines) at three different depths, the last one always ending in the nerve. The number values in the legend indicate the distance of drill from the nerve. 
Table 1 Predictive value of using impedance features to classify if the drill tip is $0-1,1-2$, and 2-3 mm away from the nerve (for $N=96$ performed drillings with an X-ray indication of the distance)

\begin{tabular}{lccc}
\hline \hline & Ratio method $(\mathrm{SZ})(\%)$ & Ratio and slope $(\mathrm{SZ}+\mathrm{ZR})(\%)$ & 100 \\
\hline Predictive value being in nerve & 97 & 100 & 100 \\
Predictive value for $0.1-1 \mathrm{~mm}$ from nerve & 100 & 94 & 100 \\
Predictive value for $1-2 \mathrm{~mm}$ & 88 & 77 & 100 \\
Predictive value for $2-3 \mathrm{~mm}$ & 77 & 100 \\
\hline \hline
\end{tabular}

more rapidly when we are far away from the nerve, and when we get closer to nerve the slop of the curve becomes very shallow and almost flat. Again, this behavior was confirmed to be seen in all test subjects. In fact, the difference between 1 and $10 \mathrm{MHz}$ amplitude is just about $3 \%$ (ratio of $1.03 \pm 0.01$ ). As is evident from Table 1, using these features gives a very reliable way to detect the proximity of the nerve. In Table 1 , the predictive value simply tells in how many cases over all of our measurements, we made a right prediction using these high-frequency features versus the ground truth that was established from X-rays. In our analysis, we were using the distance information from X-rays as ground truth, but due to the possible projection effects it is clear that the distance estimates from $\mathrm{X}$-rays have a possible error that we estimate could be at the level of $\pm 0.05-0.1 \mathrm{~mm}$. In the future work, we prose to reduce those errors by the use of better 3D X-ray measurement methods.

For ZR (impedance ratios using our selected frequency points) we find that the mean value is 1.06 (with standard deviation 0.014, where no outliers are removed from the data) when the nerve is contacted, and mean value of 1.10 (with standard deviation of 0.04 ) when the distance to nerve is $0.1-1 \mathrm{~mm}$ according to the CBCTs. For the overall slope measure, the means (and standard deviations) for the same frequency ranges are $-0.036(0.015)$ and $-0.14(0.08)$, respectively. We note that all these values are over the complete dataset and include uncertainties in X-ray projection measurements. We did not remove any outliers or uncertain measurement points from the dataset.

In Table 2, we show the results for the nerve proximity prediction in steps of $1 \mathrm{~mm}$. We show results for using progressively three different features defined earlier that are measured from the

Table 2 An example table with the radiological distances found between the drill tip and the nerval canal in the jaw number 1 is shown below

\begin{tabular}{lcc}
\hline \hline Drilling site & Drilling step & Millimeter distance to nerval canal \\
\hline 34 & 01 & 4.87 \\
34 & 02 & 2.03 \\
34 & 03 & -5.10 into nerval canal \\
33 & 01 & 3.86 \\
33 & 02 & 1.16 \\
33 & 03 & 3.58 into nerval canal \\
32 & 01 & 1.51 \\
32 & 02 & -4.66 into nerval canal \\
32 & 03 & 3.76 \\
31 & 01 & 1.92 \\
31 & 02 & 4.08 into nerval canal \\
31 & 03 & 1.42 \\
41 & 01 & -5.14 into nerval canal \\
41 & 02 & 3.07 \\
41 & 03 & 2.18 \\
42 & 01 & -4.12 into nerval canal \\
42 & 02 & 3.79 \\
42 & 03 & 1.00 \\
43 & 01 & 4.70 \\
43 & 02 & 1.71 \\
43 & 03 & -6.26 into nerval canal \\
44 & 01 & 02
\end{tabular}

data: SZ alone, SZ and ZR together (our baseline approach), and all three features together (i.e., using SZ and two different ZR values, or equivalently combining indication from SZ, ZR, and phase value change).

As can be seen, all the methods provide a very accurate warning when the drill is within $1 \mathrm{~mm}$ distance from the nerve. The accuracy can be enhanced by using different values, such as SZ and ZR together to find out the proximity of the nerve. Such a combination of data ensures good accuracy information to stop $2 \mathrm{~mm}$ before the nerve. One has to also note that in the table we show the probability of a correct classification of the distance. In fact, the situation is even better if we separate false positives (sensitivity) from the false negatives. When we analyze our data, we find that in the range of $1-2 \mathrm{~mm}$ all errors $(12 \%$ and $6 \%$ of drillings at that distance) are actually false positives, that is, our threshold analysis would warn us about approaching nerve contact while actually being further from the nerve. In the case of the range of 2-3 mm away from the nerve, also $6 \%$ of reported errors are false positives, that is, threshold values are falsely indicating that one should stop drilling further.

As discussed above the overall frequency sweep in our measurements took from 9.4 to $18.4 \mathrm{~s}$. The normal was $9.4 \mathrm{~s}$, but the measurement time increases depending on how many samples in each measurement point is taken for the averaging, and even more strongly depended on the receiver frequency bandwidth (frequency resolution). The long-sweep time measurements were required as in this initial study we did not have no a priori knowledge, which frequency bands could exhibit interesting information on the proximity of the nerve. The impedance measurements themselves can be done fast, and we did initial testing with our setup what would be required if we needed just 10 points, we can lower the measurement time to about $30 \mathrm{~ms}$, that is, we would have $30 \mathrm{~Hz}$ sampling rate. With a dedicated measurement device and fixed-point measurements, this can be done even faster, the main parameters that fix the measurement speed are required receiver bandwidth and the number of frequencies we need to measure. The receiver bandwidth has a stronger effect, but we also assume that we could safely use also bandwidths that are significantly larger than $100 \mathrm{~Hz}$, but this would be for the future work to gage-and particularly it should be confirmed with human anatomy. However, considering the relatively slow rpm of an implant drill we argue that $20-50$ measurements/s already is a sufficient measurement rate, especially as rpm's are very slow when the drill is advanced into the bone structure.

\section{Discussion}

Our results show that impedance measurements have a high potential to provide clinically useful, real-time information about the proximity to the alveolar nerve. The most interesting novel finding of our measurements is that combining several impedance features and using also higher frequency ratios provides characteristically strong information on the closeness of the drill to nerve. Based on our data this information can be used as a reliable estimator of alveolar nerve proximity.

We emphasize that such wide-bandwidth measurements as reported in our study are not required for an operational clinical device. We believe that it should be possible to develop a lowcost, small, and very fast measurement device that is connected to 


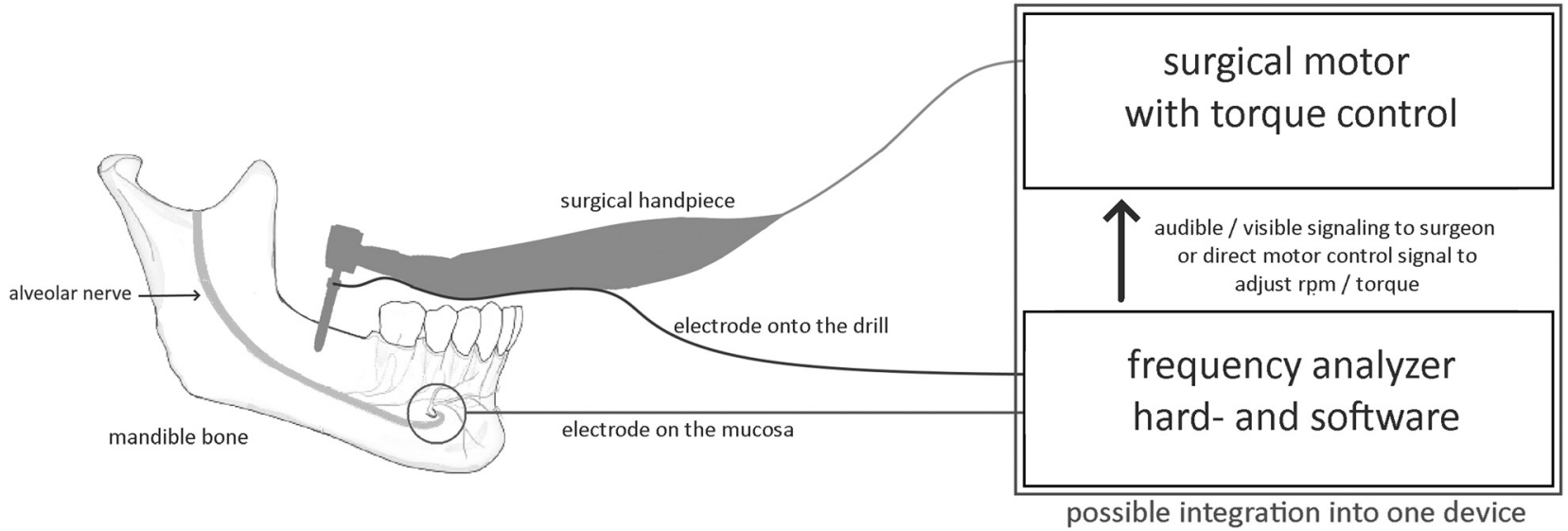

Fig. 7 A schematic description for the proposed system

the handpiece-most likely the size of the current apex locators used in endodontic treatments. Even integration into surgical motor units should be feasible.

The consistency of the gathered data shows a recurring decrease of the slope and impedance rations (and the phase shift at the high frequencies) when the electrode (the drill) is about $2 \mathrm{~mm}$ away from the nerve canal. We propose that this indicates the inner side of the cortical layer and could, therefore, be a valuable indicator for a future in vivo application.

To the best of our knowledge, this is the first study to examine and confirm that impedance measurements over such a large scale of frequencies can be used in the context of dental implantology and we believe that the reported results show that accurate nerve proximity indicators could be developed for clinical use. Also, to our best knowledge, this is the first practical proposal for a path to develop a method that can assist dental professionals in vivo, intra-operationally to avoid errors that the preoperational planning might have caused for implant surgery.

A possible further benefit of this system is the ability to place implants as deep as safely possible. This maximum insertion depth could reduce the necessity for or reduce the needed height of a bone buildup.

The real-time, high-frequency impedance measurements can provide a new avenue to provide real-time "impedance tomography" information for operating surgeons. The current measurements were done with a relatively small number of subjects and are not in vivo. These early results show the high potential of the proposed method and indicate that further studies are well warranted. The further studies should establish statistically larger samples of subjects and finally in vivo test measurement would provide further information to verify the method in a realistic environment. Nevertheless, the current results indicate that the proposed method is likely to work and that further studies should be conducted to develop this method to the clinical testing level.

If clinical testing also provides a proof of concept, the system could be integrated into surgical handpiece motors. The signal could be transferred internally within the handpiece much alike the integration of apex locators into endodontic motors. The second electrode would be placed as an intra-oral probe. The measurement process could provide an acoustic or visual signal to the surgeon when the nerve is approached. In this case, the software could also be programed to reduce the RPM and torque and stop or rewind the drill at a predefined distance. In this way, the system could provide a real-time distance monitoring during the drilling process (Fig. 7).

We note that our novel method does not render other safety measures obsolete. Special anamneses, preoperative (3D) X-rays, 3D planning with navigation splints, depth stops, intra-operative palpation and parallelization pins, and so forth will all remain a necessity, especially because they are done not only to prevent damage to the alveolar nerve but also a lot of other possible complications too.

A 3D navigation via splint or robotic arm may provide a reliable depth stop while drilling but is also susceptible to systematic [10] or application errors. The setup described above would be the only system known to the authors able to distinguish whether drilling if the drill is still safely inside the bone or is approaching the nerve.

Other real-time surgical monitoring devices are still at an early application stage and have not made it to wide or regular clinical usage. One example is the use of augmented reality, in the way that a real-time positioning of the dental handpiece with a drill/implant gives an audible and or visible feedback to the surgeon [11].

Systems like the Navident (ClaroNav, Canada) work with optical trackers attached to the surgical handpiece and the patient's jaw. Using these can correlate a preoperative CBCT to the position of the patient and the drill inside the handpiece and navigate the surgeon to a predefined position for the implant [12].

Real-time, intra-operative X-ray position controlling, likewise in the orthopedic surgery field, does not appear applicable at this time. Yet future advances in the field of the nonionizing terahertzimaging techniques might open up possibilities for such a realtime positioning under an indirect view [13].

These systems all work in real-time but are suboptimal due to faults occurring in the preoperational planning and or inaccurate X-ray data [14] and cannot be validated intra-operatively.

Due to the lack of comparability between this animal-based setup and in vivo conditions this method may face further technical challenges. Conductive liquids like blood and saliva in the live operational field may influence the signal transmission as well as the electric activity of the alveolar nerve or the whole N. mandibularis, though the described frequency analysis offers a way to circumnavigate this problem.

The design of the implant drills used to measure may have to be adjusted to meet the requirements for electric conductivity or the pick-up point of the signal within the handpiece for this system, but if needed we see this as a relatively easy product development issue for manufacturers.

Further studies could also investigate the applicability to other fields of surgery or as an additional reinsurance to surgery with robotic systems.

\section{Conclusion}

This study demonstrated that the concept of measuring the proximity of a conductive drill to the alveolar nerve via frequency analysis is applicable under in vitro conditions with a sheep jaw. The refinement of this method and subsequent development of equipment for an in vivo test and a possible widespread application should be the subject of further studies. 


\section{References}

[1] Gaviria, L., Salcido, J. P., Guda, T., and Ong, J. L., 2014, "Current Trends in Dental Implants," J. Korean Assoc. Oral Maxillofac. Surg., 40(2), pp. $50-60$.

[2] Juodzbalys, G., Wang, H.-L., Sabalys, G., Sidlauskas, A., and Galindo-Moreno, P., 2013, "Inferior Alveolar Nerve Injury Associated With Implant Surgery,' Clin. Oral Implants Res., 24(2), pp. 183-190.

[3] Hammerle, C., Jensen, S., Jokstad, A., Katsuyama, H., Kleinheinz, J., Kunavisarut, C., Mardas, N., Monje, A., Papaspyridakos, P., Payer, M., Schiegnitz, E., Smeets, R., Stefanini, M., Bruggenkate, C. T., Vazouras, K., Weber, H.-P., Weingart, D., and Windisch, P., 2018, "Group 1 ITI Consensus Report: The Influence of Implant Length and Design and Medications on Clinical and Patient-Reported Outcomes," Clin. Oral Implants Res., 29, pp. 69-77.

[4] Clark, D., Barbu, H., Lorean, A., Mijiritsky, E., and Levin, L., 2017, "Incidental Findings of Implant Complications on Postimplantation CBCTs: A CrossSectional Study," Clin. Implant Dent. Relat. Res., 19(5), pp. 776-782.

[5] Fokas, G., Vaughn, V. M., Scarfe, W. C., and Bornstein, M. M., 2018, "Accuracy of Linear Measurements on CBCT Images Related to Presurgical Implant Treatment Planning: A Systematic Review," Clin. Oral Implants Res., 29(S16), pp. 393-415.

[6] Khazaei, S., Mosleh, H., Razavian, H., and Vali, A., 2014, "Electronic Apex Locator: A Comprehensive Literature Review: Part II: Effect of Different Clinical and Technical Conditions on Electronic Apex Locator's Accuracy," Dent. Hypotheses, 5(4), p. 133.

[7] Williams, P. A., and Saha, S., 1996, "The Electrical and Dielectric Properties of Human Bone Tissue and Their Relationship With Density and Bone Mineral Content," Ann. Biomed. Eng., 24(2), pp. 222-233.
[8] Gabriel, C., Gabriel, S., and Corthout, E., 1996, "The Dielectric Properties of Biological Tissues-I: Literature Survey," Phys. Med. Biol., 41(11), pp. 2231-2249.

[9] Nam, K. C., Kim, S. C., Lee, S. J., Kim, Y. J., Kim, N. G., and Kim, D. W., 2002, "Root Canal Length Measurement in Teeth With Electrolyte Compensation," Med. Biol. Eng. Comput., 40(2), pp. 200-204.

[10] Wismeijer, D., Joda, T., Flügge, T., Fokas, G., Tahmaseb, A., Bechelli, D., Bohner, L., Bornstein, M., Burgoyne, A., Caram, S., Carmichael, R., Chen, C.Y., Coucke, W., Derksen, W., Donos, N., El Kholy, K., Evans, C., Fehmer, V., Fickl, S., Fragola, G., Gonzales, B. G., Gholami, H., Hashim, D., Hui, Y., Kökat, A., Vazouras, K., Kühl, S., Lanis, A., Leesungbok, R., van der Meer, J., Liu, Z., Sato, T., De Souza, A., Scarfe, W. C., Tosta, M., van Zyl, P., Vach, K. Vaughn, V., Vucetic, M., Wang, P., Wen, B., and Wu, V., 2018, "Group 5 ITI Consensus Report: Digital Technologies," Clin. Oral Implants Res., 29(S16), pp. 436-442.

[11] Hung, K., Huang, W., Wang, F., and Wu, Y., 2016, "Real-Time Surgical Navigation System for the Placement of Zygomatic Implants With Severe Bone Deficiency," Int. J. Oral Maxillofac. Implants, 31(6), pp. 1444-1449.

[12] Somogyi-Ganss, E., Holmes, H. I., and Jokstad, A., 2015, "Accuracy of a Novel Prototype Dynamic Computer-Assisted Surgery System," Clin. Oral Implants Res., 26(8), pp. 882-890.

[13] Bessou, M., Chassagne, B., Caumes, J. P., Pradère, C., Maire, P., Tondusson, M., and Abraham, E., 2012, "Three-Dimensional Terahertz Computed Tomography of Human Bones," Appl. Opt., 51(28), p. 6738.

[14] D'Haese, J., Van De Velde, T., Komiyama, A., Hultin, M., and De Bruyn, H., 2010, "Accuracy and Complications Using Computer-Designed stereolithographic Surgical Guides for Oral Rehabilitation by Means of Dental Implants: A Review of the Literature," Clin. Implant Dent. Relat. Res., 14(3), pp. 321-335. 


\section{Zusammenfassung}

Dissertation zur Erlangung des akademischen Grades:

Dr. med. dent.

Titel:

Avoiding the Alveolar Nerve Via a Real-Time Impedance Analysis: A Novel Method to Improve Implant Surgery Safety

eingereicht von

Georg Schiffers

angefertigt an der

RWTH Aachen, Klinik für Mund-, Kiefer- und Gesichtschirurgie sowie der

Universität Leipzig, Klinik und Poliklinik für Mund-, Kiefer- und Plastische Gesichtschirurgie

betreut von Univ.-Prof. Dr. med. Dr. med. dent. Bernd Lethaus, MHBA

November 2020

Der Artikel „Avoiding the Alveolar Nerve Via a Real-Time Impedance Analysis: A Novel Method to Improve Implant Surgery Safety" der der angestrebten Publikationspromotion zugrunde liegt, wurde am 18. Februar 2020 im „Journal of Medical Devices“ der „American 
Association of Mechanical Engineers" online, und in der Juni Ausgabe des Journals schriftlich, veröffentlicht.

Um dentale Implantate im Unterkiefer in sicherer Entfernung vom N. alveolaris inferior, bei gleichzeitig maximaler Ausnutzung des vorhandenen Knochens als Implantatlager, positionieren zu können, müssen eine Reihe von Vorsichtsmaßnahmen (Beispielsweise Planung am DVT) getroffen werden. Diese sind in der Regel prä- oder postoperativ und lassen sich intraoperativ nicht oder nur schwer anwenden.

Um hier eine Verbesserung zu erlangen, stellen wir in dieser Studie ein neuartiges Verfahren vor, welches sich die Impedanzwerte zwischen dem Bohrer bzw. dem Implantat und dem umgebenden Gewebe zunutze macht, um den Abstand zum Nerven intraoperativ und in Echtzeit zu messen.

Anders als die bisher in der Zahnheilkunde, z.B. in der Endometrie, eingesetzten Impedanzmessungen nutzen wir sehr viel höhere Frequenzen. Auch wird nicht statisch bei einer Frequenz gemessen. Stattdessen durchfahren wir einen Frequenzbereich von $100 \mathrm{~Hz}$ bis ca. 200 Mhz und messen hierbei die Impedanz als Verlaufskurve.

Um dieses Verfahren zu validieren wurde ein entsprechender, der Nullhypothese widersprechender, tierkadaverexperimenteller Versuchsaufbau gewählt. In Schafskiefern wurden jeweils 3 konsekutive Bohrungen (innerhalb der kortikalen Schicht, innerhalb der Spongiosa und innerhalb des Nervenkanals) mit gleichzeitiger Impedanzmessung an $\mathbf{4 0}$ Bohrstellen vorgenommen. Der tatsächliche Abstand zum Nerven wurde nach jedem einzelnen Bohrschritt mit einem DVT ermittelt.

Wie bereits aus Vorversuchen zu erwarten war, lässt sich auch in dieser Studie bei niedrigeren Frequenzen von $100 \mathrm{~Hz}$ bis ca. $10 \mathrm{KHz}$ (je nach angewendetem Algorithmus und Kalibrierung) einem generellen Impedanzlevel ein definierter Abstand zum Nerven zuordnen. Neue Befunde aus der Auswertung des weiteren Kurvenverlaufs zwischen 100 und $200 \mathrm{MHz}$ zeigen, dass sich auch mehrere andere Parameter der Verlaufskurven Distanzwerten reproduzierbar zuordnen lassen. 
Die Zuverlässigkeit der Abstandsmessung lässt sich weiter verbessern, wenn neben der reinen Impedanz ebenfalls Informationen aus deren Phasenverschiebung herangezogen werden.

Die Resultate belegen, dass sich die Interpretationen der Impedanz und ihrer zugeordneten Eigenschaften als zuverlässiger Indikator für den Abstand des Bohrers / Implantates zum Nerven nutzen lässt und widerlegen damit die Nullhypothese.

Bei weiteren Studien und eventuellen, klinischen Versuchsaufbauten sollte der technische Aufbau optimiert werden. Hierzu sollten vor allem die signifikantesten Frequenzeigenschaften isoliert betrachtet werden, um einen schnelleren Mess- und Steuerungsalgorithmus zu realisieren. Sobald eine klinische Erprobung ausreichend positive Daten gesammelt hat, könnte ein entsprechend optimiertes Verfahren in ein kommerziell verfügbares System, zuvorderst in einen chirurgischen Motor, integriert werden.

Ein derartiges System wäre zusätzlich prädestiniert, neben manuellen chirurgischen Verfahren, auch in einem computergesteuerten Operationssystem eingesetzt zu werden, da diesem naturgemäß eine taktile Rückmeldung fehlt.

Abschließend bleibt festzuhalten das weitere technische, präklinische und klinische Studien von Nöten sind, um das Verfahren weiter zu bewerten und gegebenenfalls zu etablieren. 


\section{Literaturverzeichnis}

[1] Gaviria, L., Salcido, J. P., Guda, T., and Ong, J. L., 2014, “Current

Trends in Dental Implants," J. Korean Assoc. Oral Maxillofac. Surg., 40(2), pp.

$50-60$.

[2] Juodzbalys, G., Wang, H.-L., Sabalys, G., Sidlauskas, A., and Galindo-Moreno,

P., 2013, "Inferior Alveolar Nerve Injury Associated With Implant Surgery,"

Clin. Oral Implants Res., 24(2), pp. 183-190.

[3] Hammerle, C., Jensen, S., Jokstad, A., Katsuyama, H., Kleinheinz, J., Kunavisarut,

C., Mardas, N., Monje, A., Papaspyridakos, P., Payer, M., Schiegnitz, E.,

Smeets, R., Stefanini, M., Bruggenkate, C. T., Vazouras, K., Weber, H.-P.,

Weingart, D., and Windisch, P., 2018, “Group 1 ITI Consensus Report: The

Influence of Implant Length and Design and Medications on Clinical and

Patient-Reported Outcomes," Clin. Oral Implants Res., 29, pp. 69-77.

[4] Clark, D., Barbu, H., Lorean, A., Mijiritsky, E., and Levin, L., 2017, “Incidental

Findings of Implant Complications on Postimplantation CBCTs: A Cross-

Sectional Study," Clin. Implant Dent. Relat. Res., 19(5), pp. 776-782.

[5] Fokas, G., Vaughn, V. M., Scarfe, W. C., and Bornstein, M. M., 2018,

“Accuracy of Linear Measurements on CBCT Images Related to Presurgical

Implant Treatment Planning: A Systematic Review," Clin. Oral Implants Res.,

29(S16), pp. 393-415.

[6] Khazaei, S., Mosleh, H., Razavian, H., and Vali, A., 2014, “Electronic Apex 
Locator: A Comprehensive Literature Review: Part II: Effect of Different Clinical and Technical Conditions on Electronic Apex Locator's Accuracy," Dent.

Hypotheses, 5(4), p. 133.

[7] Williams, P. A., and Saha, S., 1996, "The Electrical and Dielectric Properties of Human Bone Tissue and Their Relationship With Density and Bone Mineral Content," Ann. Biomed. Eng., 24(2), pp. 222-233.

[8] Gabriel, C., Gabriel, S., and Corthout, E., 1996, "The Dielectric Properties of Biological Tissues-I: Literature Survey," Phys. Med. Biol., 41(11), pp. 2231-2249.

[9] Nam, K. C., Kim, S. C., Lee, S. J., Kim, Y. J., Kim, N. G., and Kim, D. W., 2002, "Root Canal Length Measurement in Teeth With Electrolyte Compensation," Med. Biol. Eng. Comput., 40(2), pp. 200-204.

[10] Wismeijer, D., Joda, T., Fl€ugge, T., Fokas, G., Tahmaseb, A., Bechelli, D., Bohner, L., Bornstein, M., Burgoyne, A., Caram, S., Carmichael, R., Chen, C.Y., Coucke, W., Derksen, W., Donos, N., El Kholy, K., Evans, C., Fehmer, V., Fickl, S., Fragola, G., Gonzales, B. G., Gholami, H., Hashim, D., Hui, Y., K€okat, A., Vazouras, K., K€uhl, S., Lanis, A., Leesungbok, R., van der Meer, J., Liu, Z., Sato, T., De Souza, A., Scarfe, W. C., Tosta, M., van Zyl, P., Vach, K., Vaughn, V., Vucetic, M., Wang, P., Wen, B., and Wu, V., 2018, “Group 5 ITI Consensus Report: Digital Technologies," Clin. Oral Implants Res., 29(S16), pp. 436-442.

[11] Hung, K., Huang, W., Wang, F., and Wu, Y., 2016, “Real-Time Surgical Navigation 
System for the Placement of Zygomatic Implants With Severe Bone

Deficiency," Int. J. Oral Maxillofac. Implants, 31(6), pp. 1444-1449.

[12] Somogyi-Ganss, E., Holmes, H. I., and Jokstad, A., 2015, “Accuracy of a Novel Prototype Dynamic Computer-Assisted Surgery System," Clin. Oral Implants Res., 26(8), pp. 882-890.

[13] Bessou, M., Chassagne, B., Caumes, J. P., Prade`re, C., Maire, P., Tondusson, M., and Abraham, E., 2012, "Three-Dimensional Terahertz Computed Tomography of Human Bones," Appl. Opt., 51(28), p. 6738.

[14] D’Haese, J., Van De Velde, T., Komiyama, A., Hultin, M., and De Bruyn, H., 2010, “Accuracy and Complications Using Computer-Designed stereolithographic Surgical Guides for Oral Rehabilitation by Means of Dental Implants: A Review of the Literature," Clin. Implant Dent. Relat. Res., 14(3), pp. 321-335. 


\section{Erklärung über den wissenschaftlichen Beitrag des Promovenden}

Der Promovend Georg Schiffers hat die vorliegende Studie maßgeblich wissenschaftlich durchgeführt. Georg Schiffers hatte die initiale Idee zum beschriebenen Verfahren und entwickelte diese mit Hilfe von Prof. Mähönen technisch durch die Phase der Vorversuche bis hin zur finalen, veröffentlichten Studie und ist Erstautor des vorliegenden Artikels.

Julian Arnold hat die technische Betreuung der Datenaufnahme und Auswertung erbracht.

Dr. Alexander Bartella hat während der tierexperimentellen Studien, inkl. der Röntgenaufnahmen, unterstützt.

Prof. Petri Mähönen hat die maßgebliche technische Betreuung und Entwicklung der gesamten Studie von den ersten Vorversuchen bis hin zur Veröffentlichung ermöglicht und begleitet.

Prof. Bernd Lethaus hat die Konzeption und Betreuung der gesamten veröffentlichten Studie sowie die maßgebliche medizinische Betreuung während der gesamten Studie als auch der Vorversuche erbracht.

Prof. Bernd Lethaus

Univ.-Prof/Dr. Dr. B. Lethaus

Direktor der Klink und Poliklinik

füm Mund Kiefer- und Plastische

Ort, Datum

Gum Mund
Gesiohtschiruigie Leipzig, den

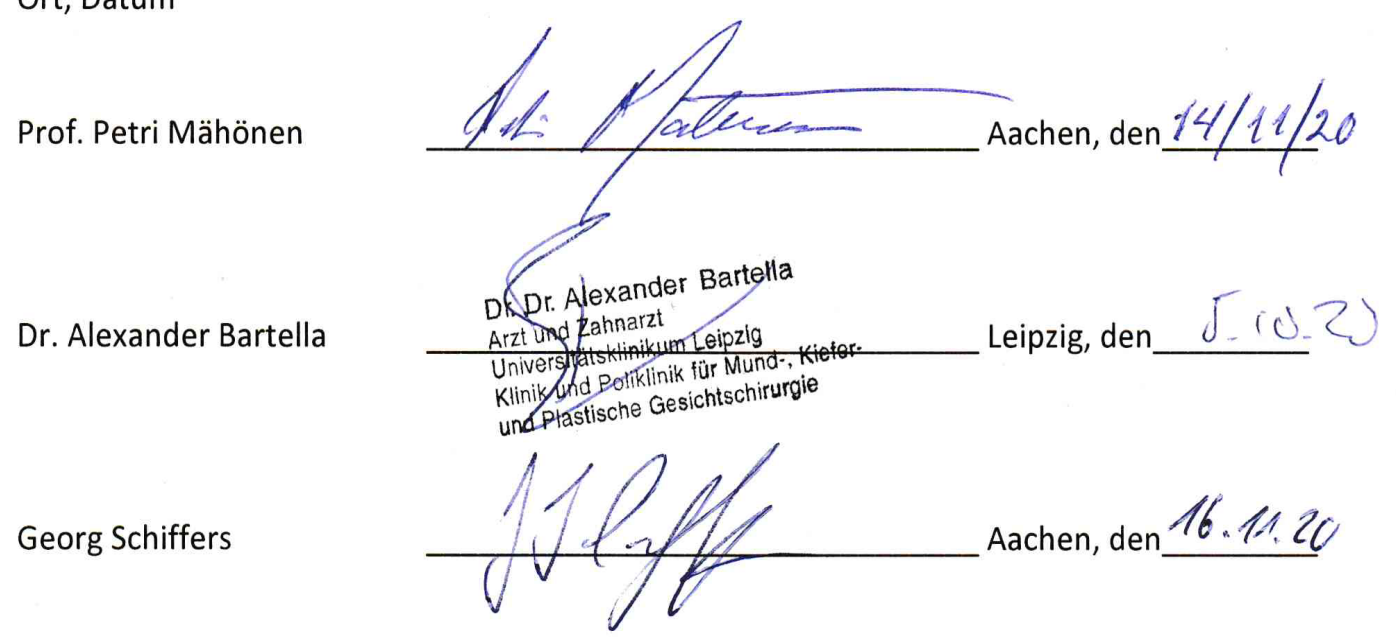




\section{Erklärung über die eigenständige Abfassung der Arbeit}

Hiermit erkläre ich, dass ich die vorliegende Arbeit selbstständig und ohne unzulässige Hilfe oder Benutzung anderer als der angegebenen Hilfsmittel angefertigt habe. Ich versichere, dass Dritte von mir weder unmittelbar noch mittelbar eine Vergütung oder geldwerte Leistungen für Arbeiten erhalten haben, die im Zusammenhang mit dem Inhalt der vorgelegten Dissertation stehen, und dass die vorgelegte Arbeit weder im Inland noch im Ausland in gleicher oder ähnlicher Form einer anderen Prüfungs-behörde zum Zweck einer Promotion oder eines anderen Prüfungsverfahrens vorgelegt wurde. Alles aus anderen Quellen und von anderen Personen übernommene Material, das in der Arbeit verwendet wurde oder auf das direkt Bezug genommen wird, wurde als solches kenntlich gemacht. Insbesondere wurden alle Personen genannt, die direkt an der Entstehung der vorliegenden Arbeit beteiligt waren. Die aktuellen gesetzlichen Vorgaben in Bezug auf die Zulassung der klinischen Studien, die Bestimmungen des Tierschutzgesetzes, die Bestimmungen des Gentechnikgesetzes und die allgemeinen Datenschutzbestimmungen wurden eingehalten. Ich versichere, dass ich die Regelungen der Satzung der Universität Leipzig zur Sicherung guter wissenschaftlicher Praxis kenne und eingehalten habe. 


\section{Lebenslauf}

\section{Persönliches}

Georg Schiffers

geboren am 12.7.1981 in Geilenkirchen

verheiratet, 2 Kinder

Schulische Ausbildung

Kath. Grundschule Geilenkirchen

priv. bischöfl. Gymnasium St. Ursula Geilenkirchen, Abitur 2001

Auslandsaufenthalt 1998 - The King's School Sydney, Australien

\section{Studium}

2001 bis 2003 vorklinischer Studienabschnitt an der Universität Leipzig Abschluss mit dem Physikum

2003 bis 2007 klinische Studienabschnitt Universität zu Köln

Abschluss mit dem Staatsexamen im Mai 2007

\section{Beruflicher Werdegang}

2007 bis 2013 Vorbereitungsassistent, später Partner in der Praxisklinik für Zahnheilkunde am Luisenhospital Aachen

2014 bis dato

Selbstständig in der Praxis für Zahnheilkunde

Schiffers \& Kollegen 
in Geilenkirchen

Seit 2010 Zertifizierung im Bereich Endodontie / VDZE

\section{Wissenschaftliches Engagement}

Seit 2008 wissenschaftliche Zusammenarbeit mit der RWTH Aachen Institut für Vernetzte Systeme iNets und der Klinik für Mund-, Kiefer- und Gesichtschirurgie der Universitätsklinik der RWTH Aachen,

seit 2019 angestrebte Publikationspromotion an der Universität Leipzig Klinik und Poliklinik für Mund-, Kiefer- und Plastische Gesichtschirurgie mit dem Thema der Impedanzmessung in der Implantologie.

Weitere wissenschaftliche Zusammenarbeit mit dem iNets mit den Themen:

Nutzung von Wirbelströmen (Eddy Currents) zur Metallfragmentdetektion in Hart- und Weichgeweben, Veröffentlichung 2021 geplant

Spectrometergesteuerte Polymerisationssteuerung dentaler Kunststoffe, Veröffentlichung geplant

Außeruniversitäre Entwicklung eines Systems zur navigierten Wurzelspitzenresektion in Zusammenarbeit mit einem Industriepartner, mehrere Vorträge zu diesem Thema, Bildung einer überörtlichen Arbeitsgruppe 


\section{Danksagung}

Mein Dank gilt Prof. Dr. Bernd Lethaus, der sich, zuerst and der Universität Aachen als dann auch an der Universität Leipzig, mit großem Engagement für diese Studie eingesetzt hat.

Ohne seine fachliche Führung wäre diese Studie nicht realisierbar gewesen.

Mein besonderer Dank gilt auch meinen Eltern Maria und Alfons Schiffers, die mich durch meinen gesamten Werdegang stets mit größtmöglichem Einsatz unterstützt haben.

Mein größtmöglicher Dank gilt Prof. Petri Mähönen ohne den diese Studie und die gesamte vorangegangene Entwicklung nicht denkbar gewesen wären.

Er hat immer wieder mit größtem persönlichem Einsatz, über einen Zeitraum von mehr als 10 Jahren, für das Fortschreiten des Themas gesorgt und die technischen Innovationen überhaupt erst ermöglicht. 